\title{
Editorial (ERPP Issue 11.2)
}

\author{
Oon Seng Tan
}

Received: 16 April 2012 / Accepted: 18 April 2012 / Published online: 12 May 2012

(C) Springer Science+Business Media B.V. 2012

Welcome to the second issue of ERPP for the year 2012. This issue presents an exciting range of perspectives on issues faced by educators and policymakers in Malaysia, Vietnam, Singapore, Hong Kong and the Sultanate of Oman.

In the first paper, Pauline Goh outlines the challenges faced by teacher educators in an era of standards-based educational transformation. She considers attempts to improve the quality and outcomes of education in Malaysia specifically, and discusses the Malaysian Teacher Standards launched in 2009 to establish high standards for the teaching profession and to increase the status of teachers in Malaysia. She outlines the challenges facing the standards systems that teacher educators may face and proposes avenues to consider in the re-design of teacher education.

Peeraer and Petegem conduct a study on Vietnam's vision on ICT in education. The authors discuss an analysis that spans a decade of governmental policy guidelines on ICT in education. In considering the impact of the policies on practice, Peeraer and Petegem argue that gaps between the two arise from issues in planning.

Wong, Chong, Choy and Lim examine the changes in levels of pedagogical knowledge and skills by student teachers from the beginning of their initial teacher preparation program to the end of their first year of teaching within the context of the Post Graduate Diploma in Education program at the National Institute of Education, Singapore. Student teachers' perceptions were determined via the Pedagogical Knowledge and Skills in Teaching (PKST) survey which comprises of six components; Student Learning, Lesson Planning, Instructional Support, Accommodating Diversity, Classroom Management, and Care and Concern. The authors consider the implications of their results for pre-service teacher education.

Pang considers Hong Kong teachers' stress in working with challenging students. The author begins by painting a picture of recent social, economic, and educational developments in Hong Kong and how these contribute to teacher stress. Data from an international study on teacher stress with respect to working with challenging students is analysed and examined. Negative affect, self-critical attitudes and the self-efficacy beliefs of teachers were

O. S. Tan $(\bowtie)$

National Institute of Education, Nanyang Technological University, Singapore, Singapore

e-mail: oonseng.tan@nie.edu.sg 
found to be more important than school characteristics. In addition, Hong Kong teachers were found to be subjected to the most negative impact and to have the most negative beliefs in working with challenging students. Remedies for relieving stress levels of teachers in Hong Kong are considered.

Al-Issa and Al-Bulushi describe and discuss impediments to English language teaching reforms in the Sultanate of Oman. The Sultanate of Oman is one of the developing countries around the world that has placed immense importance on the English language. Yet success has been elusive for their reform programmes. And this is despite the allocation of huge budgets and resources for improving the teaching of the English language. Results of their study show hardly any significant changes after two waves of reform. The authors discuss this pattern of findings attributing them primarily to implementation issues.

It is hoped that the papers in this issue will provoke further discussions between researchers, educators and policy makers, and provide avenues for collaborations to improve educational policies and practices globally. We look forward very much to your valuable contributions to future issues of the ERPP. 